\title{
Review
}

\section{Current status of tropical fruit breeding and genetics for three tropical fruit species cultivated in Japan: pineapple, mango, and papaya}

\author{
Tatsushi Ogata $^{1)}$, Shinsuke Yamanaka ${ }^{1)}$, Moriyuki Shoda ${ }^{2)}$, Naoya Urasaki') and Toshiya Yamamoto*3) \\ 1) Tropical Agriculture Research Front, Japan International Research Center for Agricultural Sciences, 1091-1, Maezato-Kawarabaru, \\ Ishigaki, Okinawa 907-0002, Japan \\ 2) Okinawa Prefectural Agricultural Research Center, 820 Makabe, Itoman, Okinawa 901-0336, Japan \\ 3) NARO Institute of Fruit Tree Science, 2-1 Fujimoto, Tsukuba, Ibaraki 305-8605, Japan
}

Tropical fruit crops are predominantly produced in tropical and subtropical developing countries, but some are now grown in southern Japan. Pineapple (Ananas comosus), mango (Mangifera indica) and papaya (Carica papaya) are major tropical fruits cultivated in Japan. Modern, well-organized breeding systems have not yet been developed for most tropical fruit species. Most parts of Japan are in the temperate climate zone, but some southern areas such as the Ryukyu Islands, which stretch from Kyushu to Taiwan, are at the northern limits for tropical fruit production without artificial heating. In this review, we describe the current status of tropical fruit breeding, genetics, genomics, and biotechnology of three main tropical fruits (pineapple, mango, and papaya) that are cultivated and consumed in Japan. More than ten new elite cultivars of pineapple have been released with improved fruit quality and suitability for consumption as fresh fruit. New challenges and perspectives for obtaining high fruit quality are discussed in the context of breeding programs for pineapple.

Key Words: fruit quality, mango, molecular marker, papaya, pineapple.

\section{Introduction}

More than 1000 species of tropical fruits are found in the tropical Americas, versus about 500 in Asia, about 300 in the Indian subcontinent, and about 1200 in Africa (Paull and Duarte 2011). Morton (1987) describes 107 species from 35 families for tropical fruits, excluding citrus species.

The production of tropical fruits differs greatly among species. Among fruit that is consumed fresh, banana (Musa acuminata Colla) has the biggest annual production, at $107 \mathrm{Mt}$ in 2013 (FAOSTAT 2013). Mango (Mangifera indica L.), pineapple (Ananas comosus (L.) Merr.), papaya (Carica papaya L.), and avocado (Persea americana Mill.) account for $75 \%$ of the remaining $22 \mathrm{Mt}$ of fresh fruit produced in 2013 (FAOSTAT 2013). Currently, 98\% of tropical fruits are produced in tropical developing countries (FAO 2003).

Breeding and genetic studies of tropical fruits are underdeveloped compared with temperate fruit crops, as most improvements have come from the selection of chance seedlings, open-pollinated seedlings, or mutations, although

Communicated by H. Iketani

Received October 4, 2015. Accepted December 7, 2015.

*Corresponding author (e-mail: toshiya@affrc.go.jp) crossbreeding by means of controlled pollination has been carried out in pineapple, papaya, and avocado. Some tropical fruit crops are difficult to breed. For example, Cavendish bananas, which dominate international trade, are triploids, which are difficult to produce by crossbreeding. Mango trees have small flowers, which produce few pollen grains, and the high fruit drop rate results in the production of few seeds by controlled pollination. Mangosteen (Garcinia mangostana L.) sets fruits parthenocarpically, and male flowers have not been reported (Paull and Duarte 2012), so crossbreeding is not practical. Some tropical fruit crops have an extremely long juvenile period, such as durian (Durio zibethinus Murray), at seven to ten years (Paull and Duarte 2012).

Because of the large number of tropical fruit species, and because a good, comprehensive book has been produced that describes the breeding of many tropical fruit crops (Jain and Priyadarshan 2009), it would be impractical to repeat that information. Instead, we describe the current status of tropical fruit breeding and related research activities of pineapple, mango, and papaya, which are cultivated and consumed in Japan. We focus on 1) pineapple breeding programs for high fruit quality in Japan, 2) several activities on genetics, genomics, and biotechnology in pineapple and mango, and 3) biotechnology in papaya. 
Table 1. Area, production and import of tropical fruits in Japan

\begin{tabular}{|c|c|c|c|c|c|}
\hline Common name & Scientific name & Major cultivars $^{a}$ & $\begin{array}{l}\text { Area } \\
(\text { ha })^{b}\end{array}$ & 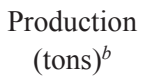 & 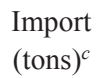 \\
\hline Pineapple & Ananas comosus & N67-10, Soft Touch, Bogor & 311 (harvested) & $6,590.0$ & 166,295 \\
\hline Mango & Mangifera indica & Irwin, Keitt & 442.9 & $2,880.9$ & 7,354 \\
\hline Passionfruit & Passiflora edulis & Summer Queen, Ruby Star, Tainung No. 1 & 62.0 & 360.0 & - \\
\hline Banana & Musa acuminata & Shima Banana (Ogasawara) & 39.3 & 181.4 & 946,205 \\
\hline Dragon fruit (Pitahaya) & Hylocereus undatus & & 22.6 & 167.7 & - \\
\hline Papaya & Carica papaya & & 16.2 & 164.9 & 2,722 \\
\hline Acerola & Malpighia emarginata & & 9.9 & 31.0 & - \\
\hline Star fruit (Carambola) & Averrhoa carambola & & 1.7 & 20.2 & - \\
\hline Atemoya & Annona atemoya & & 7.5 & 11.1 & - \\
\hline Litchi (Lychee) & Litchi chinensis & & 4.2 & 6.2 & 368 \\
\hline Guava & Psidium guajava & & 0.9 & 2.5 & - \\
\hline Avocado & Persea americana & & - & - & 57,600 \\
\hline Durian & Durio zibethinus & & - & - & 110 \\
\hline Mangosteen & Garcinia mangostana & & - & - & 98 \\
\hline
\end{tabular}

${ }^{a}$ Yonemoto (2006).

${ }^{b} 2012$ except pineapple (2013). Statistical Yearbook of Ministry of Agriculture, Forestry and Fisheries.

c 2014, fresh fruit. Trade Statistics of Japan.

\section{Production of tropical fruits in Japan}

As most parts of Japan are temperate, open-field cultivation of tropical fruit crops is impractical anywhere except in some southern areas such as the Ryukyu Islands. Some tropical fruits are grown in other areas in heated greenhouses, but they represent only a small proportion of the total crop. Southern areas of Japan are relatively warm, but the winter temperature is much lower than that in the tropics. The mean monthly temperature in January is lower than $18^{\circ} \mathrm{C}$, but the temperature sometimes drops to $10^{\circ} \mathrm{C}$ or even $5^{\circ} \mathrm{C}$ in winter, which can lead to tree damage, and low fruit production. Southern Japan is therefore at the northern limit of the northern hemisphere for tropical fruit production without heating. Another problem is that southern Japan is frequently visited by typhoons (intense tropical storms), which greatly restrict the cultivation of perennial crops such as fruit trees. The main tropical fruits grown in Japan in open fields are, therefore, pineapple and dragon fruit (or pitahaya, Hylocereus undatus (Haw.) Britton \& Rose), which can tolerate strong winds to a certain extent. To avoid the wind damage caused by typhoons, other tropical fruits are commonly grown in windproof greenhouses. The cultivation area, production, and import of tropical fruits in Japan are summarized in Table $\mathbf{1}$.

Importation of fresh fruits into Japan from foreign countries is restricted because of quarantine regulations. Most fresh tropical fruits cannot be imported, except for immature banana, pineapple, durian, tamarind (Tamarindus indica L.), and coconut (Cocos nucifera L.). Avocado and mango from certain countries are also exceptions. Mango, mangosteen, dragon fruit, and litchi (or lychee, Litchi chinensis Sonn.) fruits can be imported from some countries after a specified treatment such as vapor heating. The main reason for these restrictions is to prevent invasion by alien fruit flies and melon flies that could infest other crops, since these are among the most destructive agricultural pests worldwide. Japan eradicated melon flies in 1986, and eradicated fruit flies in 1993 from the Ryukyu Islands, which was the only area they had invaded in Japan.

Most tropical fruit cultivars in Japan were selected from cultivars that had been developed in other countries. However, because of differences in climate from their regions of origin, their performance is often worse than in their native habitats. To increase the production and consumption of tropical fruits in Japan, it is therefore important to breed new cultivars capable of thriving under Japan's climate and to improve cultivation techniques and marketing. In addition, as the taste of foreign cultivars may not suit the Japanese palate, it will be necessary to develop cultivars with taste and other characteristics desirable in the Japanese market. Currently, few tropical fruit cultivars are registered in Japan. As of 2015/8/1 (including expired registrations), there were 12 cultivars of pineapple ('N67-10', 'Soft Touch', 'Honey Bright', 'Minipa', 'Okunoao', 'Okunaka', 'Summer Gold', 'Yugafu', 'Natsuhime', 'Gold Barrel', 'Julio Star', 'Sensuous'), two of papaya ('Ishigaki Sango', 'Ishigaki Wondrous'), two of passionfruit (Passiflora edulis Sims) ('Amaminojanbou', 'Soft Touch'), one of mango ('Aiko'), and one of dragon fruit ('Chiyuramiyarabi'). Further research and development will therefore be necessary to breed new cultivars highly suited to the Japanese market.

\section{Pineapple breeding for high fruit quality}

Pineapple belongs to the family Bromeliaceae. The family includes 56 genera and ca. 2600 species, most of which are distributed from central America to the northern regions of Argentina and Chile. Pineapple is the most important economic plant in the Bromeliaceae, and originated between 
$10^{\circ} \mathrm{N}$ to $10^{\circ} \mathrm{S}$ latitude and from $55^{\circ} \mathrm{W}$ to $75^{\circ} \mathrm{W}$ longitude. This area includes northwestern and eastern Brazil, Colombia, Guyana, and Venezuela (d'Eeckenbrugge et al. 1997).

Columbus became the first Westerner to discover pineapple, on Guadeloupe in 1493, but by then, the plant was already widely distributed in the tropical Americas, and several indigenous types had differentiated (Collins 1949, 1961, d'Eeckenbrugge et al. 1997). Pineapple was introduced into Europe in the 16th century, and it spread to tropical and subtropical Asia and Africa by the 18th century (Collins 1949). Today, pineapple is the third most important tropical fruit, after banana and mango. It is cultivated in most tropical and subtropical areas of the world. World pineapple production totaled more than $2.33 \mathrm{Mt}$ in 2012 (http://faostat3.fao.org). Most of it is consumed as fresh fruit (Loeillet 1997). However, pineapple is also used for processed products as canned slices, chilled fresh-cut chunks, juice, the source of bromelain (a mixture of meat-tenderizing enzymes), and high-quality fiber.

In Japan, pineapple is cultivated in the Ryukyu Islands (Okinawa Prefecture and the islands of Kagoshima Prefecture), which stretch from Kyushu to Taiwan. The economic cultivation of pineapple in Japan was started in the 1930s by emigrants from Taiwan (Lin 1983). Since the acidic soils of Okinawa had little organic matter, the area was considered unsuitable for crop cultivation, but proved to be suitable for pineapple. The Japanese pineapple industry prospered from the 1950s through the 1970s (Lin 1983, Watanabe 1961). After Japanese trade in processed pineapple fruits was liberalized in 1990, the proportion of fresh fruit production gradually increased. In 2013, pineapple production in Japan was $6.59 \mathrm{kt}$ (Ministry of Agriculture, Forestry and Fisheries Statistical Yearbook; http://www.maff.go.jp/e/index.html), of which $65 \%$ was used for fresh fruit consumption and the remainder for processing. In contrast, $150 \mathrm{kt}$ of pineapple fruit was imported into Japan in 2013 (Ministry of Finance, Trade Statistics Japan; http://www.customs.go.jp/toukei/ info/index_e.htm).

\section{Major breeding programs around the world}

The three most economically important traditional pineapple cultivars in the world are 'Cayenne', 'Singapore Spanish', and 'Queen' (d'Eeckenbrugge et al. 1997). Three other cultivars ('Red Spanish', 'Perola', and 'Manzana') are cultivated in their regions of origin for local markets (d'Eeckenbrugge et al. 1997). 'Smooth Cayenne' is the most important cultivar owing to its high yield potential and favorable characteristics as a fresh fruit and for processing. Therefore, 'Smooth Cayenne' is the principal cultivar used around the world for pineapple breeding (Leal and d'Eeckenbrugge 1996).

The first pineapple breeding program was carried out in Florida, USA, with the goal of obtaining cultivars that were better adapted to local conditions and that had better fruit quality. Subsequently, similar programs were developed in Hawaii (USA), South Africa, India, Malaysia, Côte
d'Ivoire, and Brazil (d'Eeckenbrugge et al. 1997, Leal and d'Eeckenbrugge 1996). The objective of the world's major breeding programs has been improvement of 'Smooth Cayenne'. However, as markets for fresh fruit developed, fruit quality became an increasingly important characteristic. Therefore, the objective of breeding in most programs gradually shifted from high yield and processability to high quality of the fresh fruit.

The most successful breeding program was conducted by the Pineapple Research Institute (PRI) in Hawaii, whose goal was to breed cultivars as alternatives to 'Smooth Cayenne' for use as fresh fruit and for processed fruit (Williams and Fleisch 1993). Two hybrids originated from this program. For example, 'MD2' replaced 'Smooth Cayenne' in many production areas around the world. Several hybrids have been released by PRI member companies since PRI was dissolved in 1975. Pineapple breeding in many other countries has produced new cultivars, including 'Tainung 17' and 'Tainung 21' from Taiwan (Bartholomew et al. 2010, Tang et al. 2014); 'Josapine' from Malaysia (Bartholomew et al. 2010); 'Aus Jubilee', 'Aus Carnival', and 'Aus Festival' from Australia (Bartholomew et al. 2010, Sanewski 2014); and 'Imperial' from Brazil (Bartholomew et al. 2010, Cabral and de Matos 2009).

\section{Breeding programs in Japan}

In Okinawa, Japan, local adaptability tests of introduced pineapple cultivars were performed sporadically from the 1910s through the 1920s. To obtain enough planting materials to sustain a canning industry, more than 200000 vegetative clones of 'Smooth Cayenne' were imported from Hawaii between 1958 and 1963 (Miyagi 1981, Onaha 2002). Among the introduced clones, the vegetative selected cultivar 'N67-10' was selected in 1980 for its high yield for canning (Ikemiya et al. 1984). After Japanese government liberalized the processed pineapple fruits in 1990, the proportion of pineapple production intended for the fresh-fruit market gradually increased. Therefore, fruit quality became an important characteristic for the fresh fruit market.

Some breeding activities of pineapple were carried out at the Tropical Agriculture Research Center (TARC), the predecessor of the Japan International Research Center for Agricultural Sciences (JIRCAS), Okinawa Substation (19721989). Systematic cross-breeding programs started at the Okinawa Prefectural Agricultural Research Center (OPARC) in 1989 (Shoda 2011). At the beginning of the program, genetic resources and breeding lines were transferred from the TARC to OPARC. Because the subtropical climate in the Ryukyu Islands, with its mild winter and hot summer, is less than optimum for pineapple, breeding for climate adaptability is a major objective. Therefore, the program has focused on improving fruit qualities as well as increasing the production of fresh fruit. The present selection criteria for fruit characteristics are a fruit weight of 1000 to $1500 \mathrm{~g}$, a Brix content of at least $16 \%$ in the juice, juice acidity of less than $0.8 \%$, and a Brix/acidity ratio of $\geq 25$. Resistance to fruitlet 
core rot disease (caused by Fusarium ananatum) and marbling disease (caused by Pantoea ananas), resistance to mealy-bug wilt, ratooning ability, tolerance of low temperatures during winter, and wind resistance during typhoons are also major targets in current breeding programs. Supplemental Table 1 summarizes the desired market characteristics and selection criteria for pineapple in Japan.

The breeding system designed by OPARC evaluates accession characteristics in three steps: primary selection, secondary and tertiary selection, and adaptability and regional tests (Supplemental Fig. 1, Supplemental Table 2). In the first step, 4000 pineapple seedlings are obtained from 20 to 30 artificial hybridizations every year. Pineapple accessions used for hybridization are transplanted from the field into plastic pots and then incubated in a greenhouse. The flowering time is controlled by ethephon treatment to synchronize male and female materials (Bartholomew 1977, Bartholomew and Criley 1983), then hybridization is carried out without emasculation, because of the strong selfincompatibility of pineapple (Brewbaker and Gorrez 1967). The resulting seedlings are grown in a greenhouse for one year, and then plantlets with spiny leaf margins are eliminated before planting in the field. During primary selection, spring planting is used to ensure adequate vegetative growth and eliminate plants with precocious flowering. Plant vigor, growth habit, early natural flowering, and low-temperature injury are evaluated during the vegetative period, and then fruit characteristics are evaluated 20 months after planting.

Primary selection focuses on identifying fruit characteristics that show high heritability, such as the juice Brix and acidity, and on eliminating plantlets with inferior characteristics (collar of slips, knobs, multiple crowns, malformed fruit, crack of the fruit, and fruit rot). During primary selection, 40 to 60 promising individuals are selected from the 4000 seedlings. Next, during secondary and tertiary selection, the fruit, disease resistance, and vegetative shoots of selected individuals are evaluated during a summer planting, which is the standard cropping type for fresh fruit production in the Ryukyu Islands. Slices of the mother stems and leaf tips of the crowns obtained from promising accessions are then investigated in adaptability and regional tests at several locations in the Ryukyu Islands. In the final step, the characteristics related to economical cultivation are evaluated, such as fruit uniformity, ratooning ability, ethephon response, shelf life, and postharvest diseases, in different cropping types. It usually takes 15 to 16 years to breed and release new pineapple cultivars.

\section{Japanese elite cultivars}

To date, OPARC has released eight elite pineapple cultivars (Table 2, Fig. 1) and major characteristics of five representative cultivars are described.

'N67-10' (a vegetative selection from 'Hawaiian Smooth Cayenne'; Ikemiya et al. 1984) was released in 1985. The plant is vigorous and produces few slips and suckers. This cultivar ripens by late August in Okinawa. Fruit weight is about $1400 \mathrm{~g}$ and the flesh is yellowish white. This cultivar is suitable for processing.

'Soft Touch' (from 'Hawaiian Smooth Cayenne' $\times$ I-43880 ) was released in 1999. Plant vigor is moderate and plants produce an average of 6.6 slips and 0.4 suckers. This cultivar ripens in mid-July in Okinawa. Fruit weight is about $850 \mathrm{~g}$ and the flesh is creamy white. The juice Brix and acidity are around $16.0 \%$ and $0.60 \%$, respectively. This cultivar has a favorable peach-like aroma.

'Gold Barrel' (from 'Cream Pineapple' $\times$ 'McGregor ST-1'), released in 2009, matures mid-July and has high fruit quality. Plant vigor is moderate, and few slips and suckers are produced. The harvest period can be easily controlled because of its ethephon sensitivity. The fruit weight is about $1400 \mathrm{~g}$ and the flesh is yellow. The juice Brix and acidity are around $16.0 \%$ and $0.5 \%$, respectively. Eating quality is excellent.

'Julio Star' (from 'N67-10' × 'Cream Pineapple'), released in 2009, matures late July in Okinawa. Plant vigor is moderate and plants produce about five slips and few suckers. The fruit weight is about $1200 \mathrm{~g}$ and the flesh is pale yellow. The juice Brix and acidity are around $16.0 \%$ and $0.6 \%$, respectively. This cultivar has favorable characteristics of resistance to fruitlet core rot and a long shelf life.

'Okinou P17' (from 'Yugafu' × 'Summer Gold') was released in 2015, and a dominant characteristic is its high Brix (around 19\%). Plant vigor is moderate and plants produce 3.2 slips and 3.0 suckers on average. This cultivar ripens in late August. Fruit weight is about $1100 \mathrm{~g}$ and the flesh is yellowish white. The juice Brix and acidity are around

Table 2. Characters of pineapple cultivars bred in Okinawa Prefectural Agricultural Research Center, Japan

\begin{tabular}{|c|c|c|c|c|c|c|c|c|}
\hline Cultivar name & Maturation time $^{a}$ & Fruit shape & Fruit skin color & Flesh color & $\begin{array}{c}\text { Fruit } \\
\text { weight }(\mathrm{g})\end{array}$ & $\begin{array}{l}\text { Brix } \\
(\%)\end{array}$ & $\begin{array}{c}\text { Acidity } \\
(\%)\end{array}$ & $\begin{array}{c}\text { Brix/acid } \\
\text { ratio }\end{array}$ \\
\hline N67-10 & Late-August & Oblong & Yellow & Yellowish white & 1450 & 14.1 & 0.70 & 20.1 \\
\hline Soft Touch & Mid-July & Medium Ovate & Reddish orange & Creamy white & 850 & 16.2 & 0.65 & 24.9 \\
\hline Honey Bright & Mid-August & Oblong & Yellowish orange & Light yellow & 783 & 17.3 & 0.67 & 25.8 \\
\hline Summer Gold & Early-August & Oblong & Yellowish orange & Light yellow & 977 & 16.2 & 0.52 & 31.2 \\
\hline Yugafu & Mid-August & Oblong & Yellow & White & 1028 & 16.2 & 0.67 & 24.2 \\
\hline Gold Barrel & Mid-July & Oblong & Yellowish orange & Yellow & 1411 & 16.5 & 0.53 & 31.0 \\
\hline Julio Star & Late-July & Oblong & Orange & Pale yellow & 1174 & 16.0 & 0.62 & 26.1 \\
\hline Okinou P17 & Late-August & Oblong & Yellowish orange & Light yellow & 1108 & 19.3 & 0.64 & 31.3 \\
\hline
\end{tabular}

${ }^{a}$ Maturation time under natural condition in Okinawa. 


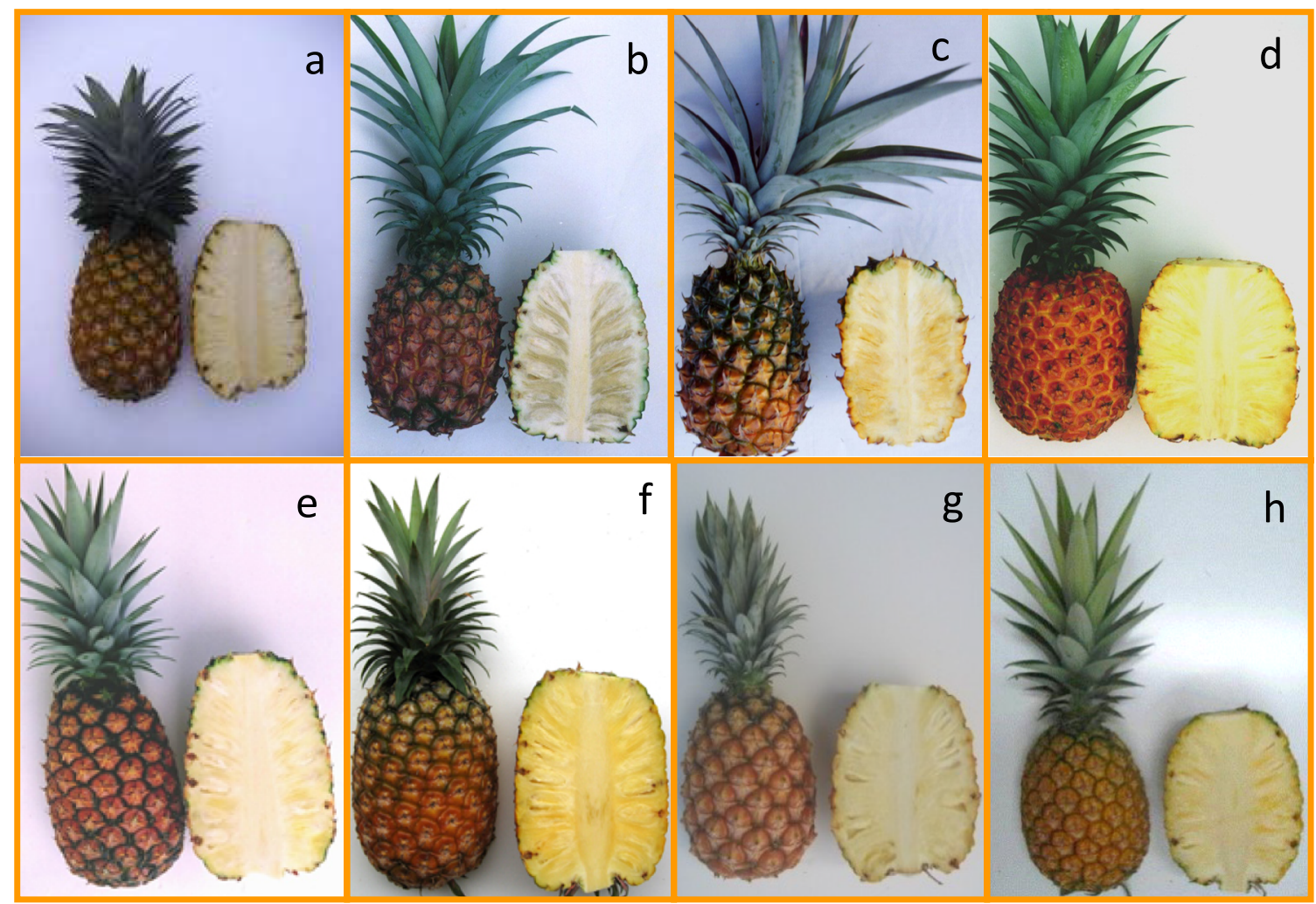

Fig. 1. Fruit appearance and longitudinal section of pineapple cultivars bred in Japan. a: N67-10; b: Soft Touch; c: Honey Bright; d: Summer Gold; e: Yugafu; f: Gold Barrel; g: Julio Star; h: Okinou P17.

$19.0 \%$ and $0.6 \%$, respectively. This cultivar has several favorable characteristics, including excellent eating quality, resistance to fruitlet core rot, and tolerance of typhoon winds.

Characteristics of three other cultivars are shown in Table 2 and Fig. 1., i.e., 'Honey Bright' (from 'Mitsubishi Smooth Cayenne' $\times$ I-43-908, released in 1999), 'Summer Gold' (from 'Cream Pineapple' × 'McGregor ST-1', released in 2004), and 'Yugafu' (from 'Cream Pineapple' $\times$ HI101, released in 2004).

New challenges and perspectives for obtaining high fruit quality

Nearly 30 years have passed since pineapple breeding started in Okinawa. 'Soft Touch', 'Summer Gold', 'Yugafu', 'Gold Barrel', and 'Julio Star' were selected from the second generation of cultivars. 'Okinou P17' was selected from the third generation and was released in 2015. More than $10 \%$ of the $\mathrm{F}_{1}$ progeny of 'Okinou P17' met the selection criteria of fruit weight (from 1000 to $1500 \mathrm{~g}$ ) and a high Brix value $(\geq 18 \%)$, whereas only $6.3 \%$ of the $F_{1}$ progeny of other cross-combinations did so (Fig. 2). These results suggest that 'Okinou P17' is an excellent cultivar for introgression of genes related to high sugar content.

Japanese pineapple breeding has focused on improving fruit quality. However, the requests from farmers, vendors, and consumers for improved fruit quality and other im- proved agronomic traits are increasing year by year. It is therefore important to establish advanced breeding techniques, such as the development of genetic markers that could be used to screen accessions for agronomic characteristics and other traits of interest. To meet this need, a new research project for comprehensive exploration of DNA polymorphisms and the development of DNA markers started in 2012 using next-generation sequencing platforms. DNA markers linked to the leaf margin phenotype and fruit characteristics (flesh color, Brix content, and maturity period) are being developed (Urasaki et al. 2015). It will be necessary to start using these and other markers in markerassisted selection (MAS), as this will shorten the period between breeding and improve the detection of promising accessions, thereby decreasing breeding time and costs.

\section{Genetics, genomics, and biotechnology in pineapple}

New genetic, genomic, and biotechnology techniques offer substantial opportunities for improving pineapple breeding. These include genetic engineering, the development of molecular markers, evaluation of genetic diversity, development of DNA markers linked with traits of interest and their use in MAS, construction of genetic linkage maps, and genome and transcriptome analyses (d'Eeckenbrugge et al. 2011, Smith et al. 2003, Zhang et al. 2014). 
a $\quad \mathrm{F}_{1}$ progenies of 'Okinou P17'

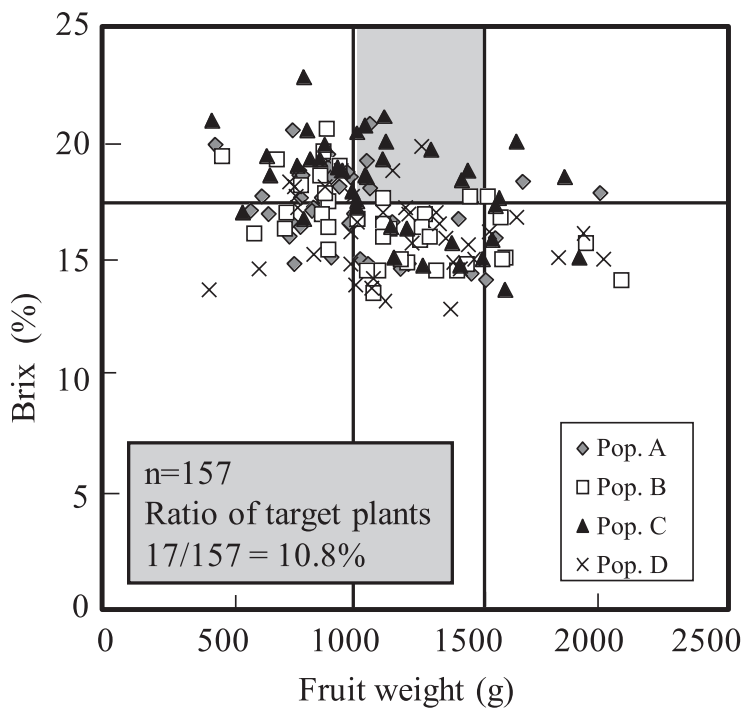

b Other $\mathrm{F}_{1}$ progenies

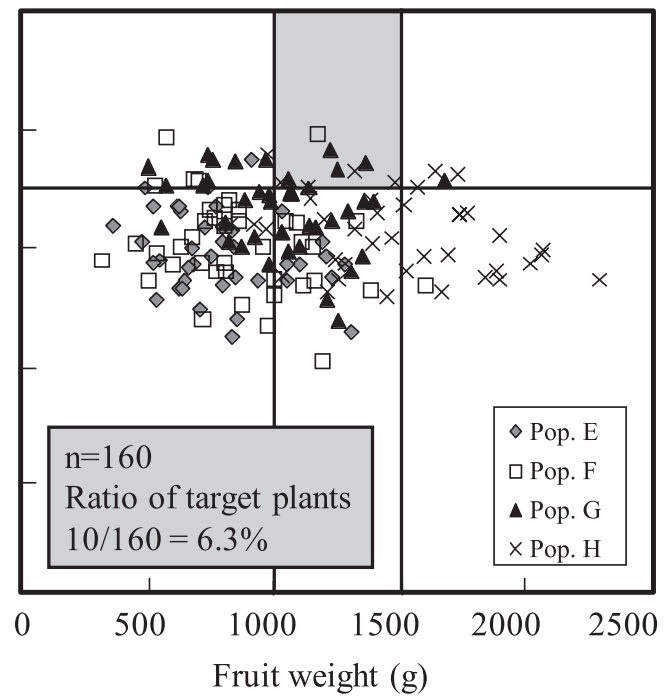

Selection criterion: 1000 to $1500 \mathrm{~g}$ for fruit weight and $>18 \%$ for Brix

Fig. 2. Frequency distribution of Brix and fruit weight for $F_{1}$ progeny of 'Okinou P17' (a) and $F_{1}$ progeny from other cross combinations (b).

\section{Genetic engineering}

Genetic transformation allows breeders to make small, targeted changes to the recipient pineapple plant's genome. Direct gene transfer and Agrobacterium-mediated transformation are both promising methods (Ko et al. 2008). Biolistics has been used to deliver genes that confer herbicide resistance in 'Smooth Cayenne' (Sripaoraya et al. 2001). The introduction of aminocyclopropane-1-carboxylic acid synthase (ACC synthase) genes via Agrobacterium inoculation has been tried to control ripening (Firoozabady et al. 2006). Field trials have been performed in the USA with pineapples genetically modified for viral and nematode resistance, delayed maturation, modified sugar composition, and flowering time (Hanke and Flachowsky 2010). More recently, the Del Monte company obtained red-fleshed 'Rosé' pineapple by combining overexpression of a gene derived from tangerine and suppression of other genes to increase the accumulation of lycopene.

\section{Molecular markers and genetic diversity}

The genetic diversity among pineapple germplasms was initially investigated using isozyme markers. DeWald et al. (1988) found that 15 out of 27 pineapple cultivars could be identified by using markers for five enzymatic systems: two peroxidases, and three phosphoglucomutases. More recently, DNA-based markers have been used to study phylogenetic and genetic relationships in Ananas; these include amplified fragment length polymorphism (AFLP), randomly amplified polymorphic DNA (RAPD), restriction-fragmentlength polymorphism (RFLP), chloroplast DNA (cpDNA) polymorphism, PCR-RFLP, and simple sequence repeat (SSR) markers.
Raus et al. (1995) evaluated four pineapple cultivars ('Perola', 'Smooth Cayenne', 'Primavera', and 'Perolera') using RAPD markers. Kato et al. (2004) evaluated 162 accessions, including 148 of $A$. comosus and 14 of related species, using AFLP markers, and found abundant genetic variation within them. Their data suggested that discrete DNA fingerprints for commercial cultivars could be detected and used for cultivar protection. Wohrmann and Weising (2011) identified 696 SSRs among 3389 expressed sequence tag (EST) unigenes, and developed primer sequences and described the locus characteristics for 18 selected EST-SSR markers. Feng et al. (2013) defined genetic diversity of 48 pineapple germplasms using 18 newly developed SSR markers.

In Japan, Shoda et al. (2012) used SSR-enriched genomic libraries to develop 18 polymorphic SSR markers which could differentiate among 18 accessions from Okinawa and 13 foreign accessions. A phenogram based on the SSR genotypes did not show any distinct groups, but it suggested that the pineapples bred in Japan are genetically diverse.

\section{DNA markers linked with traits of interest for marker- assisted selection \\ Molecular markers associated with traits of interest, and especially fruit-related traits, are valuable for MAS in pine- apple breeding programs in the world. MAS can accelerate the selection process and reduce the progeny size and the cost of raising individuals to maturity in the field (Luby and Shaw 2001). However, few DNA markers have been identi- fied that are associated with simply inherited traits, and few phenotypes have been shown to be controlled by quantita- tive trait loci (QTLs) in pineapple.}


In Japan, Urasaki et al. (2015) reported DNA markers associated with leaf margin phenotypes, which will be applicable to MAS in breeding programs. The most investigated trait concerns the presence of spines along the leaf margin, which is an important characteristic for crop management, because the presence of spines makes crop management more difficult. Collins and Kerns (1946) showed that this trait is governed by two main genes, $S$ (for spiny margins) and $P$ (for piping margins). To identify DNA markers for leaf margin phenotypes, Urasaki et al. (2015) used a restriction-site-associated DNA sequencing (RADseq) analysis to analyze three bulked DNAs of $F_{1}$ progeny from a cross between a piping-leaf type ('Yugafu') and a spiny-tip-leaf type ('Yonekura'). They successfully converted five RAD-seq tags specific to $P$ gene and two RAD-seq tags specific to $S$ gene into cleaved amplified polymorphic sequence (CAPS) or SSR markers. These molecular markers will help us to conduct MAS in pineapple breeding programs.

\section{Genetic linkage maps}

Carlier et al. (2004) published the first genetic maps of pineapple, which were constructed by using $46 \mathrm{~F}_{1}$ individuals from the cross between $A$. comosus var. comosus and var. bracteatus. The var. bracteatus map consists of 335 markers: 60 RAPD, 264 AFLP, and 11 inter-simplesequence repeat (ISSR) markers. It contains 50 linkage groups (LGs) that span $3693 \mathrm{cM}$. The var. comosus map consists of 157 markers, including markers for the piping trait, and contains $30 \mathrm{LGs}$ that span $4146 \mathrm{cM}$. Carlier et al. (2012) later constructed a genetic map of pineapple using an $\mathrm{F}_{2}$ population from a single selfed $\mathrm{F}_{1}$ plant produced by a cross between var. comosus and var. bracteatus. The map included 492 DNA markers-57 RAPD, 22 ISSR, 348 AFLP, 20 SSR, 12 EST-SSR, 25 sequence-characterized amplified region, and 8 CAPS markers-in 33 LGs. de Sousa et al. (2013) combined previous published maps of $F_{1}$ and $\mathrm{F}_{2}$ progeny to produce a new genetic map that included 741 marker loci, which were integrated into 28 LGs that spanned $2113 \mathrm{cM}$ and covered approximately $86 \%$ of the genome. No genetic maps have been constructed by using Japanese pineapple accessions.

\section{Genome and transcriptome analyses}

Moyle et al. (2005b, 2006) obtained more than 5600 ESTs related to fruit ripening and nematode-root interactions, and developed an online bioinformatics resource, PineappleDB (Moyle et al. 2005a; http://genet.imb.uq.edu. au/Pineapple/). Ong et al. (2012) sequenced the transcriptome of extracts from ripe yellow flesh using the Illumina (San Diego, CA, USA) next-generation sequencing platform. The assembly produced 28728 unique transcripts with a mean length of approximately $200 \mathrm{bp}$. Of these, $58.9 \%$ were identified as non-redundant in the NCBI database and $47.3 \%$ were mapped to 126 pathways in the Kyoto Encyclopedia of Genes and Genomes pathway database (http://www.genome.jp/kegg/). Koia et al. (2012) developed a 9277-element pineapple microarray and used it to profile the gene expression changes that occur during the ripening of pineapple fruit. Microarray analyses identified 271 unique cDNAs that were differentially expressed, by at least 1.5 times, between the mature green and mature yellow stages of ripening.

In Japan, Nashima et al. (2015a) performed random shotgun sequencing to describe the pineapple genome sequence and identified many candidate SSR sequences. They generated more than 1340000 reads, with an average length of 568 bp, for 'N67-10' using the Roche (Basel, Switzerland) 454 GS FLX+ platform. After de novo assembly, they found 51155 SSRs, comprising 33 709, $13884,2543,510$, and 509 SSRs with di-, tri-, tetra-, penta-, and hexanucleotide motifs, respectively (Supplemental Table 3). The AG/CT motif was most abundant among dinucleotide SSRs $(52.9 \%$ of the total), followed by AT/AT (38.6\%), AC/GT (8.0\%), and $\mathrm{CG} / \mathrm{CG}(0.5 \%)$. The AAG/CTT (25.8\%) and AAT/ATT (21.6\%) motifs were the dominant trinucleotide SSRs.

Nashima et al. (2015b) identified the complete chloroplast genome sequence of 'N67-10' using the 454 GS FLX+ and Illumina platform. The total length was $159636 \mathrm{bp}$, which comprised a pair of inverted repeats (each $26774 \mathrm{bp}$ ) separated by a small single-copy region of $18622 \mathrm{bp}$ and a large single-copy region of $87466 \mathrm{bp}$. Their analysis predicted 113 unique genes (79 protein-coding, 4 rRNA, and 30 tRNA genes) and 19 duplicated genes in the inverted repeats.

\section{Genetics, genomics, and biotechnology in mango}

Mango is a juicy stone fruit belonging to the family Anacardiaceae, which includes numerous tropical fruiting trees. The mango is distributed widely in the world's tropical and subtropical regions as well as in a wide range of areas with a marginal climate throughout the world. It is an economically important tree species as a cash crop. Mango is believed to have originated in India, where it has been grown for more than 4000 years, and also in areas of Southeast Asia. More than 1000 cultivars currently exist around the world (Mukherjee 1953).

In Japan, an early maturing cultivar 'Irwin' that is mainly grown in the southwest parts of Japan, such as Okinawa, Miyazaki and Kagoshima Prefectures, accounts for more than $95 \%$ of the production in Japan. Therefore, mango breeding programs in local sectors focus on high fruit quality, various harvest time from early to late maturity, adaptation for cultivation of windproof greenhouses, such as compact tree habitates, and easy judgement of maturity. Research activities on genetics, genomics, and biotechnology will help us to conduct efficient cross-breeding programs, and to breed new excellent cultivars in mango.

Genetic resources and identification of cultivars

Mango cultivars can be divided into two groups based on 
their embryo types: the monoembryonic (Indian) type is predominantly distributed in subtropical areas, and the polyembryonic (Southeast Asian) type is most common in tropical areas (Iyer and Degani 1997, Viruel et al. 2005). The Indian type possesses a zygotic (sexually produced) embryo, and the fruit skin is mainly red, whereas the Southeast Asian type has several nucellar embryos (produced from the mother plant), and the skin is mainly green to yellow (Iyer and Degani 1997, Viruel et al. 2005). In Japan, the monoembryonic 'Irwin' cultivar (developed in USA) occupies most of the commercial production as mentioned above. Only one Japanese cultivar ('Aiko') is currently registered in Japan.

Outbreeding, the wide range of climatic conditions prevailing in mango's different growing areas, and widespread hybridization and recombination of characteristics have contributed to the high genetic diversity in mango (Ravishankar et al. 2000). There has been considerable confusion in the nomenclature of mango cultivars because of the use of synonyms for many cultivars, which increases the difficulty of identifying cultivars (Krishna and Singh 2007). To efficiently and effectively utilize mango's diverse genetic resources, it is first necessary to characterize the available germplasm. As in the case of pineapple, the use of DNA markers can contribute to cultivar identification. Breeding projects can be improved by taking advantage of DNA markers for MAS, since this will decrease the number of generations needed for gene introgression and will facilitate the identification of genetically different parents to generate heterosis (Lavi et al. 2004).

\section{Molecular markers and applications}

The initial molecular markers used for mango were isozyme markers, which were used in a survey of genetic variation (Gan et al. 1981) and for the identification of loci that are polymorphic among cultivars (Degani et al. 1990). Schnell et al. (1995) used RAPD markers to fingerprint cultivars and estimate the genetic relationships among mango accessions. They evaluated a group of putative 'Haden' seedlings using 11 RAPD primers. Adato et al. (1995) evaluated the genetic relationships among 26 mango cultivars and 14 mango rootstocks, and provided a pedigree that further confirmed the relationships among many of the 'Haden' seedlings accessions. Lopez-Valenzuela et al. (1997) used RAPD markers to estimate the genetic diversity of 15 mango cultivars and identified a specific RAPD band that was associated only with the polyembryonic type. Kashkush et al. (2001) utilized AFLP markers to estimate the genetic relationships among 16 cultivars and 7 rootstocks. In Japan, Ueda and Higuchi (2012) surveyed the genetic diversity of local Okinawan mango genetic resources using ISSR markers and compared it with that of 17 international cultivars: the Okinawan mangoes possessed greater diversity than the other cultivars in terms of the number of fragments and the polymorphism ratio. Thus, isozyme, RAPD, ISSR, and AFLP markers have been used to identify mango cultivars, evaluate their genetic relationships, and confirm that crosspollination has occurred (Arias et al. 2012, Krishna and Singh 2007, Lavi et al. 2004).

Shudo et al. (2013) developed CAPS markers and used them to confirm the parentage of $F_{1}$ progeny during the breeding process. They developed CAPS markers based on the sequences of sucrose synthase (SS) and sucrose phosphate synthase (SPS) genes from 19 mango cultivars. Based on the SNPs and indels they found in both genes, they developed 26 CAPS markers for $S S$ and 32 CAPS markers for SPS.

\section{SSR markers and genetic diversity}

SSR markers have advantages over many other marker types: they are highly polymorphic, have multiple alleles, and are co-dominant. SSRs have been widely utilized for the conservation of genetic resources and in population genetics, molecular breeding, and paternity testing studies (Ellegren 2004). In mango, SSR markers are particularly important in the identification of cultivars, the determination of genetic variability, germplasm conservation, and identifying the domestication and movement of germplasm (Viruel et al. 2005). More than 100 SSR markers have been developed by using different mango germplasms (Chiang et al. 2012, Duval et al. 2005, Honsho et al. 2005, Ravishankar et al. 2011, Schnell et al. 2005, Viruel et al. 2005). Schnell et al. (2006) used 25 SSRs to estimate the genetic diversity among 203 mangos and five accessions of related species cultivated and maintained in Miami, Florida. The 25 SSRs revealed an average of 6.96 alleles per locus and an average polymorphic information content value of 0.552 among the mango accessions. The 25 SSRs they used for the 208 accessions were moderately polymorphic, suggesting that this number is adequate for studies of genetic diversity and parentage. Hirano et al. (2010) used 11 SSRs to conduct a phylogeographical analysis of Myanmar mango landraces, which they compared with accessions from Florida, India, and Southeast Asia. Tsai et al. (2013) used 37 SSRs to identify cultivars and estimate their genetic relationships of 22 Taiwanese cultivars. Recently, 176 novel SSR markers were newly identified originated from 'Irwin' by using the Roche 454 GS FLX+ platform in Japan (T. Yamamoto, unpublished data).

\section{Linkage mapping}

The first linkage mapping study in mango was conducted by Kashkush et al. (2001). In this study, a linkage map based on the progeny of a cross between 'Keitt' and 'Tommy Atkins' was constructed using 34 AFLP markers, which were mapped in 13 linkage groups that covered $161.5 \mathrm{cM}$. A second linkage map was constructed by Fang et al. (2003) using 60 progeny of a cross between 'Keitt' and 'Tommy Atkins'. In this map, 39 loci were mapped in 14 linkage groups. Using whole-genome sequencing technology, several hundred SSR markers have been developed and are now being validated in mapping populations (Arias et al. 2012, 
T. Yamamoto, unpublished data), which will enable us to develop a high-density genetic map and to identify traitlinked markers for mango.

Biotechnology in papaya

In 2013, 12.4 Mt of papayas was produced around the world (FAOSTAT 2013). In Japan, papaya cultivation is concentrated in the south, where $165 \mathrm{t}$ was produced in 2012 (MAFF 2015). Papaya is a tall perennial woody plant with strong apical dominance (Nakasone and Paull 1998). It is a trioecious (Fig. 3) and autogamous species (Nakasone and Paull 1998), and is therefore propagated by seed. Pure lines and $F_{1}$ cultivars are grown around the world. For instance, the Hawaiian 'Solo' cultivar and its relatives are well known as gynodioecious pure inbred lines. Seeds are produced by selfing of hermaphroditic flowers from gynodioecious cultivars (Chan 2009, Manshardt 2014, Nakasone and Paull 1998). In India, two dioecious pure-line cultivars, 'Co1' and 'Co2', are cultivated. Their seeds are produced by crossing female and male plants of dioecious cultivars (Chan 2009). The cultivars 'Eksotika II', which was bred in Malaysia, and 'Tainung 1-3' and 'Red Lady', which were bred in Taiwan, are well-known commercial $\mathrm{F}_{1}$ cultivars (Chan 2009). Their seeds are produced by crossing two pure-line parents.

Papaya is generally grown in open fields. Therefore, the principal objective of breeding around the world has been to provide stable production by conferring resistance to papaya ringspot virus (PRSV), a devastating disease that is transmitted by aphids. In May 1992, PRSV was discovered in the Puna district of Hawaii, where more than $95 \%$ of Hawaii's papayas are produced; within three years, nearly $100 \%$ of the plants in the Puna area had been severely affected. To solve this problem, the transgenic 'Rainbow' cultivar was developed and commercialized, with virus resistance mediated by a response to the virus's coat protein (Ferreira et al. 2002, Tennant et al. 2001).

In Japan, 'Ishigaki Sango' and 'Ishigaki Wondrous' have been bred at JIRCAS (http://www.hinsyu.maff.go.jp/). 'Ishigaki Sango' and 'Ishigaki Wondrous' are (respectively) female and hermaphroditic non-pure-line cultivars. Therefore, both are propagated by means of tissue culture. In Japan, papaya is usually cultivated in windproof screen or glass houses in order to prevent papaya leaf distortion mosaic virus, PRSV, papaya mosaic virus diseases, and damage by frequent typhoons. Semi-dwarf to dwarf tree height is one of the major objectives for house farming in breeding programs of Japanese local sectors. Since immature fruits are often used, and cooked for foods in Okinawa Prefecture, immature fruit quality can be also an objective in breeding programs. Furthermore, during summer, house farming causes the hermaphroditic flowers to change into male flowers (Tamaki et al. 2011). Therefore, fruit production by the hermaphroditic plants of gynodioecious cultivars is unstable. In Japan, cultivars that do not show this seasonal sex change are required for stable production. To breed such a cultivar, it is first necessary to understand the sex determination mechanism in papaya. Thus, it is expected that biotechnology and molecular biological studies will improve breeding programs, and breed new excellent cultivars in papaya.

A draft genome sequence of the transgenic papaya cultivar 'SunUp' is now available (Ming et al. 2008). The sex of papaya is genetically determined by the pairing of sex chromosomes. Females are homogametic for the X chromosome $(\mathrm{XX})$, whereas males and hermaphrodites are heterogametic, possessing the $\mathrm{XY}$ and $\mathrm{XY} \mathrm{Y}^{\mathrm{h}}$ chromosomes, respectively. Homozygotes of $\mathrm{Y}$ and $\mathrm{Y}^{\mathrm{h}}$ chromosome as well as a heterozygote $\left(Y Y^{\mathrm{h}}\right)$ are assumed to be lethal from the segregation of sexes in progeny obtained by crossing of female and male, female and hermaphrodite, hermaphrodite and male, and selfing of hermaphrodite (Ming et al. 2011, Storey 1953). Female papaya exhibits stable sex expression, and male papaya rarely shows a floral sex change. However, as mentioned earlier, hermaphroditic trees have been known to undergo a sex change to male under the environmental conditions (Fig. 3). The genes that determine the male and hermaphroditic conditions are believed to lie in a male-specific region (MSY) and a hermaphrodite-specific region (HSY) on the $\mathrm{Y}$ and $\mathrm{Y}^{\mathrm{h}}$ chromosomes, respectively (Ming et al. 2011). These sequence differences were used to develop DNA markers for selection of the desired sex during cultivation and breeding (Urasaki et al. 2002a, b).

To identify candidate sex determination genes in papaya, transcriptomic and genomic analyses have been carried out. In the transcriptomic analysis, Matsumura et al. (2010) used a high-throughput (HT) SuperSAGE analysis. HTSuperSAGE is a method of digital gene expression profiling that involves the isolation of 26-bp tag fragments from expressed transcripts. To explore the transcripts from the sex chromosomes, Urasaki et al. (2012) performed HTSuperSAGE analysis using flower buds from male, female, and hermaphroditic papaya. They discovered 47 genes that were differentially expressed among the sexes and mapped them to the $\mathrm{X}, \mathrm{Y}$, and $\mathrm{Y}^{\mathrm{h}}$ sex chromosomes. One of the genes is a MADS-box protein gene that is present on the $\mathrm{Y}$ and $\mathrm{Y}^{\mathrm{h}}$ chromosomes but not on the $\mathrm{X}$ chromosome.

In the genomic analysis, Ueno et al. (2015) compared whole-genome sequences from male and hermaphroditic plants. They identified 14528 nucleotide substitutions, 965 short indels with a large gap, and two highly diverged regions in the MSY and HSY genomic regions. In the genes that they predicted would be expressed in flower buds, they generally found no nucleotide differences leading to amino acid changes between the MSY and HSY regions. The only exception was a MADS-box gene that existed in both MSY and HSY but not on the X chromosome. A transposon insertion was observed in this gene in the HSY region but not in the MSY region. The deduced amino acid sequences from the cDNAs showed that the MSY allele of the MADS-box gene encoded an intact protein, whereas the HSY allele 

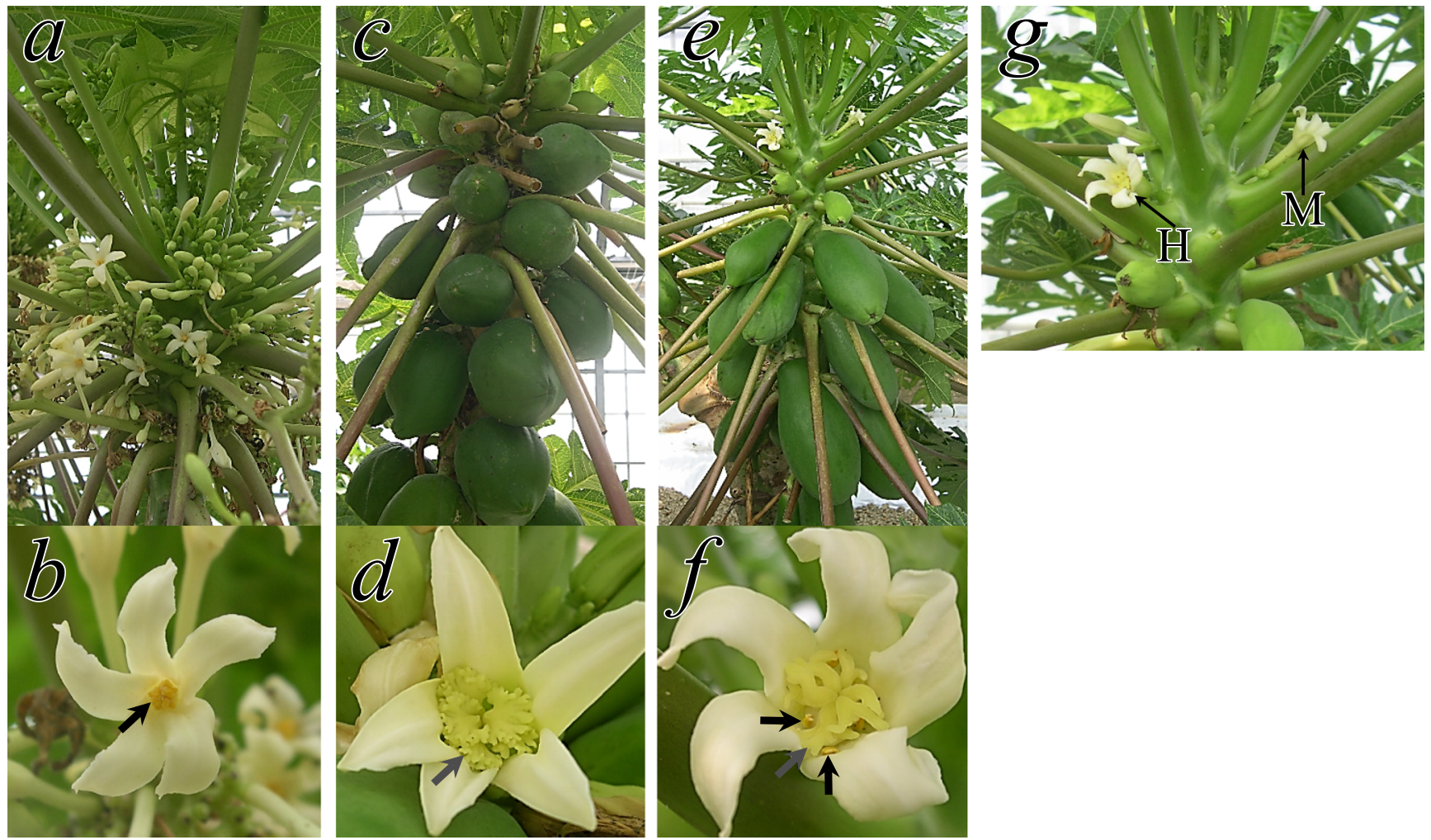

Fig. 3. Papaya, trioecious plant. $a$ and $b$ is male plant of breeding line TM1. $c$ and $d$, and, $e$ and $f$, is female and hermaphrodite of gynodioecious line TM7, respectively. $\mathrm{H}$ and $\mathrm{M}$ in $\mathrm{g}$ is hermaphrodite and sex changed male flower in a hermaphrodite plant of TM7, respectively. Black and grey arrows in $b, d$ and $f$ indicate stamen and pistil, respectively.

encoded a truncated protein. This gene was identical to the abovementioned gene obtained by transcriptome analysis. Ueno et al. (2015) designated this gene as SVP-like based on its similarity to SHORT VEGETATIVE PHASE (SVP) in Arabidopsis (Supplemental Fig. 2).

In Arabidopsis, $S V P$ was originally identified as a repressor of the floral transition. SVP controls flowering time by transcriptional regulation of the $F T$ gene (Gregis et al. 2006). According to the $\mathrm{ABC}$ model, class $\mathrm{B}$ and $\mathrm{C}$ genes define the stamen identity by acting together, whereas the class $\mathrm{C}$ genes act alone to stimulate carpel formation (Coen and Meyerowitz 1991, Weigel and Meyerowitz 1994). In Arabidopsis and other species, SVP plays roles in floral organ development via its regulation of class $\mathrm{B}$ and $\mathrm{C}$ genes (Gregis et al. 2009, Jaudal et al. 2014, Wu et al. 2012). In dioecious poplars (Populus spp.), expression of SVP-like genes was higher in male flower buds than in female buds (Song et al. 2013), suggesting that these genes might have a role in sexual development. Therefore, the SVP-like gene in papaya appears to play an important role in sex determination and provides clues to how it may be possible to produce a hermaphroditic papaya with a low frequency of sex change that is suitable for screen and glass house cultivation in Japan.

\section{Literature Cited}

Adato,A., D. Sharon and U.Lavi (1995) Application of DNA fingerprints for identification and genetic analyses of mango (Mangifera indica) genotypes. J. Amer. Soc. Hort. Sci. 120: 259-264.

Arias, R.S., J.W.Borrone, C.L.Tondo, D.N.Kuhn, B.M. Irish and R.J.Schnell (2012) Genomics of Tropical Fruit Tree Crops. In: Shunell, R.J. and P.M. Priyadarshan (eds.) Genomics of Tree Crops. Springer, New York, pp. 209-239.

Bartholomew, D.P. (1977) Inflorescence development of pineapple (Ananas comosus (L.) Merr.) induced to flower with ethephon. Bot. Gaz. 138: 312-320

Bartholomew, D.P. and R.A. Criley (1983) Tropical fruit and beverage crops. In: Nichells, L.G. (ed.) Handbook of Plant Growth Regulating Chemicals, Vol. II. CRC Press, Boca Raton Florida, pp. 1-34.

Bartholomew, D.P., G.C.d'Eeckenbrugge and C.Chen (2010) Register of new fruit and nut cultivars list, pineapple. HortScience 45: 740742.

Brewbaker, J.L. and D.D. Gorrez (1967) Genetics of self-incompatibility in the monocot genera, Ananas (pineapple) and Gasteria. Am. J. Bot. 54: 611-616.

Cabral, J.R.S. and A.P. de Matos (2009) Imperial, a new pineapple cultivar resistant to fusariosis. Acta Hortic. 822: 47-50.

Carlier, J.D., A. Reis, M.F. Duval, G.C. d'Eeckenbrugge and J.M. Leitão (2004) Genetic maps of RAPD, AFLP and ISSR markers in Ananas bracteatus and $A$. comosus using the pseudo-testcross strategy. Plant Breed. 123: 186-192.

Carlier, J.D., N.H.Sousa, T.E.Santo, G.C.d'Eeckenbrugge and J.M. 
Leitao (2012) A genetic map of pineapple (Ananas comosus (L.) Merr.) including SCAR, CAPS, SSR and EST-SSR markers. Mol. Breed. 29: 245-260.

Chan, Y.K. (2009) Breeding Papaya (Carica papaya L.). In: Jain, S.M. and P.M. Priyadarshan (eds.) Breeding Plantation Tree Crops: Tropical Species. Springer, New York, pp. 121-159.

Chiang, Y.C., C.M.Tsai, Y.K.H.Chen, S.R.Lee, C.H.Chen, Y.S.Lin and C.C. Tsai (2012) Development and characterization of 20 new polymorphic microsatellite markers from Mangifera indica (Anacardiaceae). Am. J. Bot. e117-e119.

Coen, E.S. and E.M. Meyerowitz (1991) The war of the whorls: genetic interactions controlling flower development. Nature 353: 31-37.

Collins, J.L. and K.R. Kerns (1946) Inheritance of three leaf types in the pineapple. J. Hered. 37: 123-128.

Collins, J.L. (1949) History, taxonomy and culture of the pineapple. Econ. Bot. 3: 335-359.

Collins, J.L. (1961) The pineapple; Botany, Cultivation, and Utilization. Interscience Publishers, New York, p. 294.

d'Eeckenbrugge, G., F. Leal and M.F.Duval (1997) Germplasm resources of pineapple. Hort. Rev. 21: 133-175.

d'Eeckenbrugge, G.C., G.M. Sanewski, M.K. Smith, M.F. Duval and F. Leal (2011) Ananas. In: Kole, C. (ed.) Wild Crop Relatives: Genomic and Breeding Resources, Tropical and Subtropical Fruits. Springer-Verlag, Berlin Heidelberg, pp. 21-41.

Degani, C., R.E. Bastri and S. Gazit (1990) Enzyme polymorphism in mango. J. Amer. Soc. Hort. Sci. 115: 844-847.

de Sousa, N., J. Carlier, T. Santo and J. Leitão (2013) An integrated genetic map of pineapple (Ananas comosus (L.) Merr.). Sci. Hortic. 157: 113-118.

DeWald, M.G., G.A. Moore and W.B. Sherman (1988) Identification of pineapple cultivars by isozyme genotypes. J. Amer. Soc. Hort. Sci. 113: 935-938.

Duval, M.F., J.Bunel, C.Sitbon and A.M. Risterucci (2005) Development of microsatellite markers for mango (Mangifera indica L.). Mol. Ecol. Note 5: 824-826.

Ellegren,H. (2004) Microsatellites: simple sequences with complex evolution. Nat. Rev. Genet. 5: 435-445.

Fang, J., D. Liu and Z.Ma (2003) Constructing mango (Mangifera indica L.) genetic map using markers for double heterozygous loci. Mol. Plant Breed. 1: 313-319.

FAO (2003) Medium-term prospects for agricultural commodities, FAO, p. 113.

FAOSTAT (2013) http://faostat.fao.org/

Feng, S., H. Tong, Y.Chen, J.Wang, Y.Chen, G. Sun, J.He and Y.Wu (2013) Development of pineapple microsatellite markers and germplasm genetic diversity analysis. BioMed Res. Int. 2013: Article ID 317912.

Ferreira, S.A., K.Y.Pitz, R.Manshardt, F.Zee, M.Fitch and D. Gonsalves (2002) Virus coat protein transgenic papaya provides practical control of papaya ringspot virus in Hawaii. Plant Disease 86: 101-105.

Firoozabady, E., M.Heckert and N.Gutterson (2006) Transformation and regeneration of pineapple. Plant Cell Tissue Organ Cult. 84: $1-16$.

Gan, Y.Y., S.Zaini and A. Idris (1981) Genetic variation in the grafted vegetatively propagated mango Mangifera indica. Pertanika 4: 53-63.

Gregis, V., A. Sessa, L.Colombo and M.M.Kater (2006) AGL24, SHORT VEGETATIVE PHASE, and APETALA1 redundantly control AGAMOUS during early stages of flower development in Arabidopsis. Plant Cell 18: 1373-1382.
Gregis, V., A. Sessa, C.Dorca-Fornell and M.M.Kater (2009) The Arabidopsis floral meristem identity genes AP1, AGL24 and SVP directly repress class B and C floral homeotic genes. Plant J. 60: 626-637.

Hanke, M.V. and H. Flachowsky (2010) Fruit Crops. In: Kempken, F. and C. Jung (eds.) Genetic Modification of Plants, Biotechnology in Agriculture and Forestry 64. Springer-Verlag, Berlin Heidelberg, pp. 307-348.

Hirano, R., O.T.Htun and K.N. Watanabe (2010) Myanmar mango landraces reveal genetic uniqueness over common cultivars from Florida, India, and Southeast Asia. Genome 53: 321-330.

Honsho, C., K. Nishiyama, W. Eiadthong and K. Yonemori (2005) Isolation and characterization of new microsatellite markers in mango (Mangifera indica). Mol. Ecol. Notes 5: 152-154.

Ikemiya, H., A. Onaha and H. Nakasone (1984) Excellent strain N6710 in pineapple. Kyushu Agric. Res. 46: 268.

Iyer, C.P.A. and C. Degani (1997) Classical breeding and genetics. In: Litz, R.E. (ed.) The Mango, Botany, Production and Uses. CAB International, New York, pp. 49-68.

Jain, S.M. and P.M. Priyadarshan, eds. (2009) Breeding Plantation Tree Crops: Tropical Species. Springer, New York, pp. 1-653.

Jaudal, M., J.Monash, L.Zhang, J.Wen, K.S.Mysore, R. Macknight and J.Putterill (2014) Overexpression of Medicago SVP genes causes floral defects and delayed flowering in Arabidopsis but only affects floral development in Medicago. J. Exp. Bot. 65: 429-442.

Kashkush, K., F. Jinggui, E. Tomer, J.Hillel and U.Lavi (2001) Cultivar identification and genetic map of mango (Mangifera indica). Euphytica 122: 129-136.

Kato, C.Y., C.Nagai, P.H. Moore, F.Zee, M.S. Kim, D.L. Steiger and R. Ming (2004) Intra-specific DNA polymorphism in pineapple (Ananas comosus (L.) Merr.) assessed by AFLP markers. Genet. Resour. Crop Evol. 51: 815-825.

Ko,H.L., G.M. Sanewski and M.K.Smith (2008) Pineapple. In: Kole, C. and T.C.Hall (eds.) Compendium of Transgenic Crop Plants, vol. 5, Transgenic Tropical and Subtropical Fruit and Nuts. Wiley-Blackwell, Oxford, UK, pp. 109-130.

Koia, J.H., R.L. Moyle and J.R. Botella (2012) Microarray analysis of gene expression profiles in ripening pineapple fruits. BMC Plant Biol. 12: 240.

Krishna, H. and S.K. Singh (2007) Biotechnological advances in mango (Mangifera indica L.) and their future implication in crop improvement-a review. Biotechnol. Adv. 25: 223-243.

Lavi, U., K. Kashkush, D. Sa'ada, H. Shats, U.Ravid and E.Tomer (2004) Mango breeding and the potential of modern biology. Acta Hortic. 645: 51-59.

Leal,F. and G. d'Eeckenbrugge (1996) Pineapple. In: Janick, J. and J.N. Moore (eds.) Fruit Breeding, vol I: Tree and Tropical Fruits. John Wiley \& Sons, London, pp. 515-557.

Lin, F. (1983) History of pineapple industry in Okinawa, Okinawa pineapple industrial history publication, Japan, pp. 1-610.

Loeillet, D. (1997) The world pineapple market: the importance of Europe. Acta Hortic. 425: 37-48.

López-Valenzuela,J.A., O.Martínez and O.Paredes-López (1997) Geographic differentiation and embryo type identification in Mangifera indica L. cultivars using RAPD markers. HortScience 32: 1105-1108.

Luby, J.J. and D.V. Shaw (2001) Does marker-assisted selection make dollars and sense in a fruit breeding program? HortScience 36 : 872-879.

MAFF (Ministry of Agriculture, Forestry and Fisheries of Japan) (2015) http://www.maff.go.jp/j/tokei/kouhyou/tokusan_kazyu/ (Accessed 
2015 May 1)

Manshardt, R. (2014) History and Future of the Solo Papaya. In: Ming, R. and P.H. Moore (eds.) Genetics and Genomics of Papaya. Plant Genetics and Genomics: Crops and Models 10. Springer Science + Business Media, New York, pp. 95-113.

Matsumura,H., K. Yoshida, S.Luo, E. Kimura, T.Fujibe, Z.Albertyn, R.A.Barrero, D.H.Krüger, G.Kahl, G.P. Schroth et al. (2010) High-throughput SuperSAGE for digital gene expression analysis of multiple samples using next generation sequencing. PLoS ONE 5: e12010.

Ming, R., A. Bendahmane and S.S. Renner (2011) Sex chromosomes in land plants. Annu. Rev. Plant Biol. 62: 485-514.

Ming, R., S. Hou, Y. Feng, Q. Yu, A. Dionne-Laporte, J.H. Saw, P. Senin, W.Wang, B.V.Ly, K.L.T. Lewis et al. (2008) The draft genome of the transgenic tropical fruit tree papaya (Carica papaya Linnaeus). Nature 452: 991-996.

Miyagi, T. (1981) Research review for pineapple. In: Okinawa agricultural experimental station 100 years memory magazine. pp. 378 422.

Morton, J.F. (1987) Fruits of Warm Climates. J. F. Morton, Miami, FL, p. 505 .

Moyle, R.L., M.L.Crowe, J.Ripi-Koia, D.J. Fairbairn and J.R. Botella (2005a) PineappleDB: an online pineapple bioinformatics resource. BMC Plant Biol. 5: 21.

Moyle, R., D.J.Fairbairn, J.Ripi, M.Crowe and J.R. Botella (2005b) Developing pineapple fruit has a small transcriptome dominated by metallothionein. J. Exp. Bot. 56: 101-112.

Moyle, R., J.Ripi, D.J.Fairbairn, M.Crowe and J.R. Botella (2006) The pineapple EST sequencing and microarray project. Acta Hortic. 702: 47-50.

Mukherjee, S.K. (1953) The mango-Its botany, cultivation, uses and future improvement, especially as observed in India. Econ. Bot. 7: $130-162$.

Nakasone,H.Y. and R.E.Paull (1998) Tropical Fruits. CAB International, Oxon, UK, p. 443.

Nashima, K., F. Hosaka， S.Terakami， C.Nishitani， M. Kunihisa, M. Shoda, M. Takeuchi, C. Moromizato, K. Yonamine, N. Urasaki et al. (2015a) Development of novel SSR markers from the genome sequence of pineapple. Acta Hortic. (In press)

Nashima, K, S.Terakami, C.Nishitani, M.Kunihisa, M.Shoda, M. Takeuchi, N. Urasaki, K. Tarora, T. Yamamoto and H. Katayama (2015b) Complete chloroplast genome sequence of pineapple (Ananas comosus). Tree Genet. Genomes 11: 60.

Onaha,A. (2002) Studies on the physiology and ecology of pineapple. Bull. Okinawa Agric. Exp. Sta. 25: 1-72.

Ong, W.D., L.Y.C.Voo and V.S.Kumar (2012) De novo assembly, characterization and functional annotation of pineapple fruit transcriptome through massively parallel sequencing. PLoS ONE 7: e46937.

Paull, R.E. and O.Duarte (2011) Tropical Fruits Volume 1, 2nd edn. CAB International, Wallingford, pp. 1-399.

Paull, R.E. and O.Duarte (2012) Tropical Fruits Volume 2, 2nd edn. CAB International, Wallingford, pp. 1-371.

Raus, P.M., C.F. Ruas, D.J. Fairbanks, W.R. Andersen and J.R.S. Cabral (1995) Genetic relationship among four varieties of pineapple, Ananas comosus, revealed by random amplified polymorphic DNA (RAPD) analysis. Braz. J. Genet. 18: 413-416.

Ravishankar, K.V., A.Lalitha, M.R. Dinesh and L.Anand (2000) Assessment of genetic relatedness among mango cultivars of India using RAPD markers. J. Hort. Sci. Biotech. 75: 198-201.

Ravishankar,K.V., B.H.R.Mani, L.Anand and M.R.Dinesh (2011)
Development of new microsatellite markers from mango (Mangifera indica) and cross-species amplification. Am. J. Bot. e96-e99.

Sanewski, G. (2014) 'Aus-Festival'. Plant Var. J. 27: 275-278.

Schnell, R.J., C.M. Ronning and R.J.Knight (1995) Identification of cultivars and validation of genetic relationships in Mangifera indica L. using RAPD markers. Theor. Appl. Genet. 90: 269-274.

Schnell, R.J., C.T.Olano, W.E. Quintanilla and A.W.Meerow (2005) Isolation and characterization of 15 microsatellite loci from mango (Mangifera indica L.) and cross-species amplification in closely related taxa. Mol. Ecol. Note 5: 625-627.

Schnell, R.J., J.S. Brown, C.T. Olano and A.W. Meerow (2006) Mango genetic diversity analysis and pedigree inferences for Florida cultivars using microsatellite markers. J. Amer. Soc. Hort. Sci. 131: 214-224.

Shoda, M. (2011) Pineapple: Introduction, industry and current domestic production. Food Pre. Sci. 3: 249-255.

Shoda, M., N. Urasaki, S. Sakiyama, S. Terakami, F. Hosaka, N Shigeta, C.Nishitani and T. Yamamoto (2012) DNA profiling of pineapple cultivars in Japan discriminated by SSR markers. Breed. Sci. 62: 352-359.

Shudo,A., K. Tarora, Y. Makishi, R, Ichi, K. Takahashi, M. Matsumura, S. Shimabukuro, N. Matsuda, S. Nakasone and N.Urasaki (2013) Development of CAPS markers and their application in breeding for mango, Mangifera indica L. Euphytica 190: 345-355.

Smith, M.K., H.L.Ko, S.D.Hamill, G.M. Sanewski and M.W. Graham (2003) Biotechnology. In: Bartholomew, D.P., R.E.Paull and K.G. Rohrbach (eds.) The Pineapple: Botany, Production and Uses. CAB International, Oxon, UK. pp. 57-68.

Song, Y.P., K.F. Ma, D. Ci, Q.Q. Chen, J.X. Tian and D.Q. Zhang (2013) Sexual dimorphic floral development in dioecious plants revealed by transcriptome, phytohormone, and DNA methylation analysis in Populus tomentosa. Plant Mol. Biol. 83: 559-576.

Sripaoraya, S., R.Marchant, J.B.Power and M.R.Davey (2001) Herbicide-tolerant transgenic pineapple (Ananas comosus) produced by microprojectile bombardment. Ann. Bot. 88: 597-603.

Storey, W.B. (1953) Genetics of the papaya. J. Hered. 44: 70-78.

Tamaki, M., N.Urasaki, Y. Sunakawa, K. Motomura and S.Adaniya (2011). Seasonal variations in pollen germination ability, reproductive function of pistils, and seeds and fruit yield in papaya (Carica papaya L.) in Okinawa. J. Japan. Soc. Hort. Sci. 80: 156-163.

Tang, C., M.H. Tsai, H.W. Tsai and C.S. Kusan (2014) A new variety of pineapple (Ananas comosus (L.) Merr.) ‘TN21 Golden'. J. Taiwan Agr. Res. 63: 167-177.

Tennant, P., G. Fermin, M.M. Fitch, R.M. Manshardt, J.L. Slightom and D. Gonsalves (2001) Papaya ringspot virus resistance of transgenic Rainbow and SunUp is affected by gene dosage, plant development and coat protein homology. Eur. J. Plant Pathol. 107: 645-653.

Tsai, C.C., Y.K.H.Chen, C.H.Chen, I.S.Weng, C.M.Tsai, S.R.Lee, Y.S. Lin and Y.C.Chiang (2013) Cultivar identification and genetic relationship of mango (Mangifera indica) in Taiwan using 37 SSR markers. Sci. Hortic. 164: 196-201.

Ueda, Y. and H.Higuchi (2012) Mango resources left on Okinawa Island and their diversity. Trop. Agric. Develop. 56: 1-8.

Ueno, H., N.Urasaki, S. Natsume, K. Yoshida, K. Tarora, A.Shudo, R. Terauchi and H. Matsumura (2015) Genome sequence comparison reveals a candidate gene involved in male-hermaphrodite differentiation in papaya (Carica papaya) trees. Mol. Genet. Genomics 290: 661-670.

Urasaki, N., K. Tarora, T.Uehara, I.Chinen, R. Terauchi and M. Tokumoto (2002a) Rapid and highly reliable sex diagnostic PCR 
Tropical fruit breeding and genetics in Japan

assay for papaya (Carica papaya L.). Breed. Sci. 52: 333-335.

Urasaki, N., M.Tokumoto, K.Tarora, Y.Ban, T.Kayano, H.Tanaka, H. Oku, I. Chinen and R. Terauchi (2002b) A male and hermaphrodite specific RAPD marker for papaya (Carica papaya L.). Theor. Appl. Genet. 104: 281-285.

Urasaki, N., K. Tarora, A.Shudo, H.Ueno, M.Tamaki, N. Miyagi, S.Adaniya and H. Matsumura (2012) Digital transcriptome analysis of putative sex-determination genes in papaya (Carica papaya). PLoS ONE 7: e40904.

Urasaki, N., S. Goeku, R. Kaneshima, T.Takamine, K. Tarora, M. Takeuchi, C. Moromizato, K. Yonamine, F. Hosaka, S.Terakami et al. (2015) Leaf margin phenotype-specific restriction-siteassociated DNA-derived markers for pineapple (Ananas comosus). Breed. Sci. 65: 276-284.

Viruel,M.A., P.Escribano, M.Barbieri, M.Ferri and J.I.Hormaza (2005) Fingerprinting, embryo type and geographic differentiation in mango (Mangifera indica L., Anacardiaceae) with microsatellites. Mol. Breed. 15: 383-393.

Watanabe, S. (1961) Cultivation and processing in pineapple, Ryukyu
Canned Pineapple Association, Japan, pp. 84-88.

Weigel, D. and E.M. Meyerowitz (1994) The ABCs of floral homeotic genes. Cell 78: 203-209.

Williams, D.D.F. and H.Fleisch (1993) Historical review of pineapple breeding in Hawaii. Acta Hortic. 334: 67-76.

Wohrmann, T. and K. Weising (2011) In silico mining for simple sequence repeat loci in a pineapple expressed sequence tag database and cross-species amplification of EST-SSR markers across Bromeliaceae. Theor. Appl. Genet. 123: 635-647.

Wu, R.M., E.F.Walton, A.C.Richardson, M.Wood, R.P.Hellens and E. Varkonyi-Gasic (2012) Conservation and divergence of four kiwifruit $S V P$-like MADS-box genes suggest distinct roles in kiwifruit bud dormancy and flowering. J. Exp. Bot. 63: 797-807.

Yonemoto, Y. (2006) Tropical Fruit. In: Japanese Society for Horticultural Science (ed.) Horticulture in Japan 2006. Shoukadoh Publication, Kyoto, pp. 100-106.

Zhang, J., J.Liu and R.Ming (2014) Genomic analyses of the CAM plant pineapple. J. Exp. Bot. 65: 3395-3404. 